\title{
Pericardial Lymph Node
}

National Cancer Institute

\section{Source}

National Cancer Institute. Pericardial Lymph Node. NCI Thesaurus. Code C117870.

A lymph node located anterior to the pericardium, posterior to the xiphoid process, and in the right and left cardiophrenic fat. 